\title{
An Asymmetric Synthesis of 2-Substituted Piperidines through Ozonolysis of Cyclopentenes and Reductive Aminocyclization
}

\author{
Mamoru KaWAGUCHI, ${ }^{*}$ Osamu HaYASHI, ${ }^{*}$ Noriyuki SAKAI, ${ }^{* *}$ \\ Masayuki Hamada, ${ }^{* *}$ Yukio Yamamoto \\ and Jun'ichi ODA ${ }^{\dagger}$ \\ Institute for Chemical Research, Kyoto University, \\ Uji, Kyoto 611, Japan \\ *International Reagent Corporation, 3-2, 4-chome, Takatsukadai, \\ Nishi-ku, Kobe 673-02, Japan \\ ** Department of Agricultural Chemistry, Kinki University, \\ Kowakae, 3-4-1, Higashiosaka 577, Japan
}

Received June 30, 1986

\begin{abstract}
By the action of ozone, sodium cyanoborohydride and the optically active benzylic amines 2 , the 1-substituted cyclopentenes $\mathbf{1}, \mathbf{5}$ and $\mathbf{9}$ were converted to a diastereoisomeric mixture of 1,2disubstituted piperidines (3, 6 and 10), respectively. Hydrogenation of these compounds and the following work-up yielded optically active 2 -alkylpiperidines $(4$, up to $68 \%$ e.e.), pipecolic acid (7, $84 \%$ e.e.) and 2-(hydroxymethyl)piperidine (11, up to $85 \%$ e.e.). Chromatographic separation of the major isomers of $3 \mathbf{b}$ and $\mathbf{6}$ enabled optically pure coniine (4b) and pipecolic acid (7) to be prepared, respectively.
\end{abstract}

The applicability of sodium cyanoborohydride has been well appreciated for reductive alkylation of amines. ${ }^{1)}$ The reagent has been utilized for reductive aminocyclization of dicarbonyl compounds, and selectively affords cis-2,6-disubstituted piperidines. ${ }^{2)} \mathrm{We}$ have reported novel one-pot syntheses of morpholines and azacrown ethers, which involve reduction of ozonized dihydrofurans and subsequent reductive alkylation of amines by sodium cyanoborohydride. ${ }^{3)}$

This series of reactions could be applied to an asymmetric synthesis of 2-substituted piperidines from 1-substituted cyclopentenes when an optically active amine is employed. Thus we undertook syntheses of the optically active piperidines $4 \mathrm{a}, \mathbf{4 b}, 7$ and 11, having methyl, propyl, carboxyl and hydroxymethyl groups, respectively. In the present work, chiral benzylic amines such as $(S)$-1-phenylethylamine (2a), (R)-1-(1-naphthyl)ethylamine (2b), $(R)$ - phenylglycine methyl ester (2c) and (R)-2amino-2-phenylethanol (2d) ${ }^{4)}$ were chosen as nitrogen-atom donors, because their carbonnitrogen bond could be cleaved easily by hydrogenation.

The 1-alkylcyclopentenes $\mathbf{1 a}$ and $\mathbf{1 b}^{5)}$ were treated successively with ozone and sodium cyanoborohydride. The aldehyde-ketones thus obtained were cyclized in situ with the optically active amines 2 by the action of the reducing agent to afford diastereoisomeric mixtures of the 1,2-disubstituted piperidines 3. The carbon-nitrogen bond fission by hydrogenation over palladium hydroxide on carbon gave the 2-alkylpiperidines 4 (Scheme 1). The results of the asymmetric synthesis of $\mathbf{4}$ are presented in Table I. The e.e.'s of 4a prepared by the use of $\mathbf{2 a}$ and $\mathbf{2 b}$ (entries 1 and 2) are higher than those of $4 \mathbf{a}$ yielded by using $2 \mathbf{c}$ and $\mathbf{2 d}$ (entries 3 and 4 ). The reactivity of $\mathbf{2 b}$ for $\mathbf{1 a}$ was low and it took 6 days to complete the

\footnotetext{
${ }^{\dagger}$ To whom correspondence should be addressed.
} 


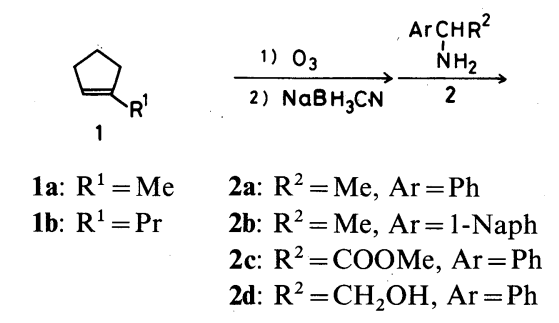

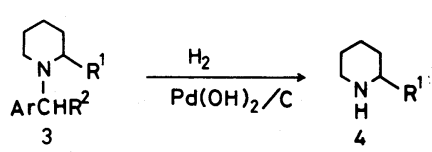

3a: $\mathrm{R}^{1}=\mathrm{Me}, \mathrm{R}^{2}=\mathrm{Me}, \mathrm{Ar}=\mathrm{Ph} \quad$ 4a: $\mathrm{R}^{1}=\mathrm{Me}$

3b: $\mathrm{R}^{1}=\mathrm{Pr}, \mathrm{R}^{2}=\mathrm{Me}, \mathrm{Ar}=\mathrm{Ph} \quad$ 4b: $\mathrm{R}^{1}=\mathrm{Pr}$

SCHEME 1. Asymmetric Syntheses of 2-Alkylpiperidines.

Table I. Asymmetric Syntheses of 2-Alkylpiperidines

\begin{tabular}{|c|c|c|c|c|c|c|c|c|}
\hline \multirow{2}{*}{ Entry } & \multirow{2}{*}{ Olefin } & \multicolumn{2}{|c|}{ Amine } & \multicolumn{5}{|c|}{ 2-Alkylpiperidine } \\
\hline & & Compound & Config. & Compound & $\begin{array}{c}\text { Overall } \\
\text { yield }(\%)\end{array}$ & Config. & {$[\alpha]_{\mathrm{D}}$} & $\begin{array}{l}\text { e.e. } \\
(\%)\end{array}$ \\
\hline 1 & $1 \mathbf{a}$ & $\mathbf{2 a}$ & $S$ & $4 a$ & 22 & $S$ & $+5.3^{\circ a}$ & 56 \\
\hline 2 & 1a & $\mathbf{2 b}$ & $R$ & $4 a$ & 19 & $R$ & $-6.3^{\circ a}$ & 67 \\
\hline 3 & 1a & $2 c$ & $R$ & - & - & - & - & $20^{c}$ \\
\hline 4 & 1a & $2 d$ & $R$ & $4 \mathbf{a}$ & 51 & $S$ & $+0.3^{\circ a}$ & 3 \\
\hline 5 & $\mathbf{1 b}$ & $2 \mathbf{a}$ & $S$ & $4 b$ & 30 & $S$ & $+5.7^{\circ b}$ & 39 \\
\hline
\end{tabular}

${ }^{a} \quad[\alpha]_{\mathrm{D} \max }^{24}-9.4^{\circ}(c=0.95, \mathrm{EtOH})$; P. C. Wälchli et al., Helv. Chem. Acta, 61, 921 (1978).

${ }^{b} \quad[\alpha]_{D \max }^{23}+14.6^{\circ}$ (neat); J. C. Craig and A. R. Pinder, J. Org. Chem., 36, 3648 (1971).

c The e.e. was estimated from the ${ }^{1} \mathrm{H}$ NMR spectrum of the intermediate 1,2-disubstituted amine, which was obtained in a yield of $83 \%$.

aminocyclization. The reaction with $\mathbf{1 b}$ and $\mathbf{2 b}$ was so slow that the corresponding 1,2-disubstituted piperidine (3) having propyl and 1-(1naphthyl)ethyl groups could not be obtained in a practical yield.

The major isomer of the diastereomeric piperidine $\mathbf{3 b}$ was successfully isolated by silica gel column chromatography. Hydrogenation of this compound afforded (S)-coniine (4b) of the natural form in a $73 \%$ yield whose specific rotation, $[\alpha]_{\mathrm{D}}^{25}+14.8^{\circ}$ (neat), coincided with that reported, $[\alpha]_{\mathrm{D}}^{23}+14.6^{\circ}$. $^{6)}$

By the same treatment of ozone, sodium cyanoborohydride and the amine 2a, methyl 1cyclopentenecarboxylate (5) was converted to a diastereoisomeric mixture of the amino ester 6 in a yield of $24 \%$ (Scheme 2). ${ }^{7)}$ Successive hydrogenation and alkaline hydrolysis of 6 yielded $(R)$-pipecolic acid (7) having $[\alpha]_{\mathrm{D}}^{21}$ $+20.4^{\circ}$ ( $c=1.0$, water), whose e.e. was calculated to be $83 \%$ based on a reported maximum rotation of $[\alpha]_{\mathrm{D}}^{23}+24.6^{\circ}(c=3.35$, water $){ }^{8)} \mathrm{As}$ to the maximum rotation of 7 , however, a quite different value of $[\alpha]_{\mathrm{D}}^{20}-30.6^{\circ}(c=1$, water) has been presented. ${ }^{9}{ }^{9}$ Because the rotation method was considered to be unreliable for determining the e.e. of 7 , a determination based on the HPLC separation was realized. Racemic- carbobenzyloxypipecolic acid was coupled with $(S)$-valine methyl ester to yield the fully protected dipeptide $\mathbf{8}$. This sample gave two base-line separated peaks with equal areas (separation factor, $\alpha=1.10$ ). Pipecolic acid (7) with $[\alpha]_{\mathrm{D}}^{21}+20.4^{\circ}$ was subjected to the analysis to exhibit a ratio of $92: 8$, and then the e.e. was calculated to be $84 \%{ }^{10}{ }^{10)}$ The major diastereoisomer of the amino ester $\mathbf{6}$ was also separated by preparative thin-layer chromatography. The same treatment of hydrogenation and hydrolysis of the separated 6 afforded 7 having $[\alpha]_{D}^{25}+24.0^{\circ}$ The HPLC analysis of the dipeptide 8 clarified that this sample was optically pure.

For the asymmetric synthesis of 2-hydroxymethylpiperidine (11), 1-(hydroxymethyl)cyclopentene (9a) and its derivatives 

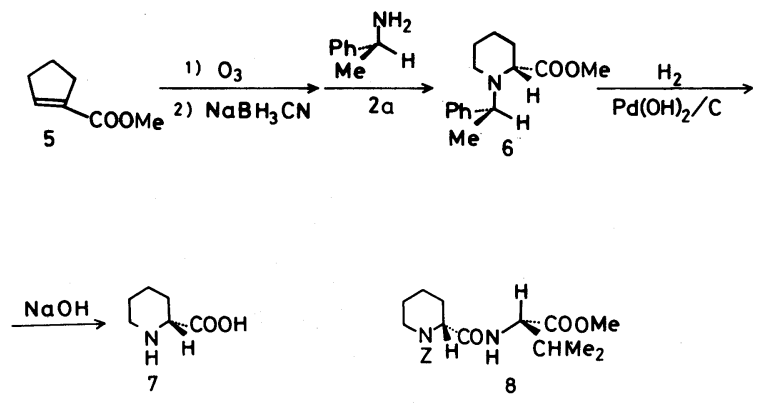

SCHEME 2. Asymmetric Synthesis of Pipecolic Acid.

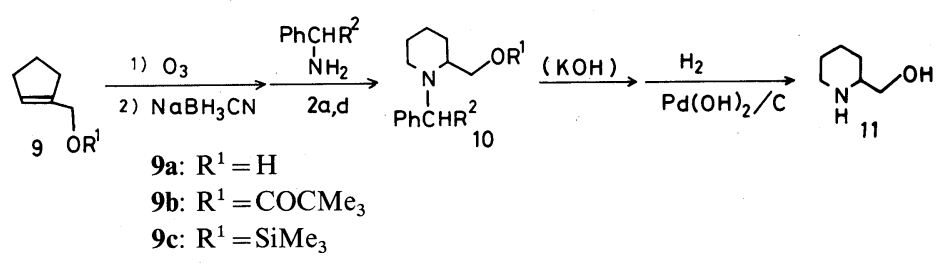

SCHEME 3. Asymmetric Synthesis of 2-Hydroxymethylpiperidine.

TABLE II. ASYMMETRIC SYNTHESIS OF 2-HYDROXYMETHYLPIPERIDINE (11)

\begin{tabular}{|c|c|c|c|c|c|c|c|}
\hline \multirow[b]{2}{*}{ Entry } & \multirow[b]{2}{*}{ Olefin } & \multicolumn{2}{|c|}{ Amine } & \multicolumn{4}{|c|}{ 2-Hydroxymethylpiperidine } \\
\hline & & Compound & Config. & $\begin{array}{c}\text { Overall } \\
\text { yield }(\%)\end{array}$ & Config. & {$[\alpha]_{\mathrm{D}}^{a}$} & $\begin{array}{l}\text { e.e. } \\
(\%)\end{array}$ \\
\hline 1 & $9 a$ & $2 \mathbf{a}$ & $S$ & 45 & $R$ & $-11.4^{\circ}$ & 71 \\
\hline 2 & $9 b$ & $2 a$ & $S$ & 58 & $R$ & $-13.5^{\circ}$ & 84 \\
\hline 3 & $9 \mathrm{c}$ & $2 a$ & $S$ & 81 & $R$ & $-10.6^{\circ}$ & 66 \\
\hline 4 & $9 a$ & $2 d$ & $R$ & 36 & $S$ & $+6.2^{\circ}$ & 39 \\
\hline
\end{tabular}

${ }^{a}[\alpha]_{\mathrm{D} \max }^{21}-16.0^{\circ}(c=2.34$, EtOH$) ; \mathrm{H}$. Ripperger and K. Schreiber, Tetrahedron, 21, 1485 (1965).

(9b and 9c) were subjected to the reaction, and the 1,2-disubstituted piperidines 10 were obtained in a similar manner. Hydrogenation of 10a gave 2-hydroxymethylpiperidine (11). The acyl group in $\mathbf{1 0 b}$ was removed by alkaline hydrolysis prior to the hydrogenation. The yields, e.e.'s and configuration of $\mathbf{1 1}$ are shown in Table II. The protecting groups of the hydroxymethyl group in 9 did not affect the ee of $\mathbf{1 1}$ remarkablly (entries $1 \sim 3$ ).

As far as (S)-1-phenylethylamine (2a) was employed as a chiral auxiliary, the orientation of the substituents was identical throughout all the 2-substituted piperidines 4, 7 and 11 prepared here. 2-Methylpiperidine (4a, Table I, entry 1) and coniine (4b, Table I, entry 5) had the $S$-configuration and the others (7 and 11) had the $R$-configuration (Scheme 2; Table II, entries $1 \sim 3)$. The discrepancy is ascribed to the priority rule of the $R, S$ notation, and those compounds actually have the same stereochemistry. This relationship between the configurations of the products and the amines (2) holds in the case of $(R)-1-(1-$ naphthyl)ethylamine (1b, Table I, entry 2). The stereocourse of the present asymmetric synthesis can be rationalized by Scheme 4 . The resulting aldehyde-ketone $\mathbf{1 2}$ from the cyclic olefin undergoes a reaction with the amine $\mathbf{2 a}$ to form the amino-ketone 13. This compound cyclizes to the iminium cation or the enamine 


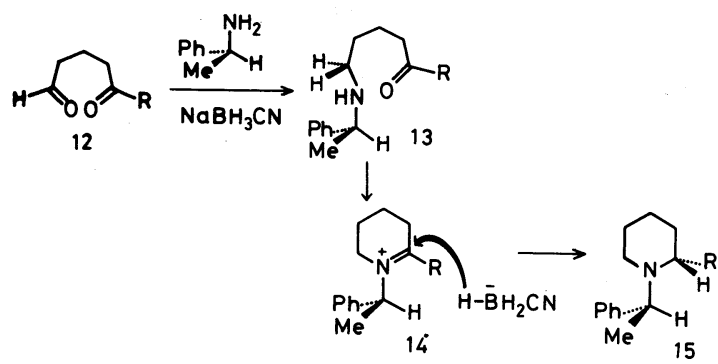

SCHEME 4. Presumable Stereocourse of the Present Asymmetric Aminocyclization.

whose probable conformation is depicted in $\mathbf{1 4}$ as the former form. When the cyanoborohydride ion attacks from the less-hindered site in which the methyl group orients, the configuration of the product leads to that shown in $\mathbf{1 5}$.

\section{EXPERIMENTAL}

${ }^{1} \mathrm{H}$ NMR spectra were recorded in $\mathrm{CDCl}_{3}$ with a Varian EM-360 spectrometer. Optical rotations were measured with a Perkin-Elmer R-241 polarimeter. HPLC analyses were carried out on a Jasco BIP-1 chromatographic system with a silica gel column (NUCLEOSIL 50-5, $4 \mathrm{~mm} \times$ $25 \mathrm{~cm}$ ); eluent, $3 \%$ 2-propanol in hexane, $0.5 \mathrm{ml} / \mathrm{min}$, detecting at $254 \mathrm{~nm}$. Elementary analyses were performed by a Yanaco MT-3 instrument. Distillation was performed with a Kugelrohr apparatus. 1-Methylcyclopentene (1a) and (R)-1-(1-naphthyl)ethylamine (2b) were purchased from Tokyo Kasei Corporation.

Asymmetric synthesis of (+)-2-methylpiperidine (4a); typical procedure for synthesizing 2-alkylpiperidines (4). Ozone gas was passed into a mixture of 1-methylcyclopentene $(1 \mathrm{a}, 1.0 \mathrm{~g}, 12.2 \mathrm{mmol}), \mathrm{MeOH}(4.1 \mathrm{ml})$ and $\mathrm{CH}_{2} \mathrm{Cl}_{2}(20 \mathrm{ml})$ at $-50^{\circ} \mathrm{C}$, until a blue color developed, indicating consumption of the olefin. After removing the excess ozone with $\mathrm{N}_{2}, \mathrm{NaBH}_{3} \mathrm{CN}(2.0 \mathrm{~g}, 31.8 \mathrm{mmol})$ was added to the solution, and the mixture was stirred at $-50^{\circ} \mathrm{C}$ for $10 \mathrm{~min}$. A solution of (-)-1phenylethylamine $^{11)}(2 \mathrm{a}, 1.5 \mathrm{~g}, 12.3 \mathrm{mmol})$ in acetonitrile $(20 \mathrm{ml})$ was added dropwise, and stirring was continued at $-30^{\circ} \mathrm{C}$ for $1 \mathrm{hr}$. Acetic acid $(0.7 \mathrm{~g}, 12 \mathrm{mmol})$ in acetonitrile $(10 \mathrm{ml})$ was added dropwise to the mixture at $-30^{\circ} \mathrm{C}$, and the mixture was stirred at $-10^{\circ} \mathrm{C}$ overnight. After removing the solvents under reduced pressure, $10 \% \mathrm{NaOH}$ $(30 \mathrm{ml})$ was added. The mixture was extracted with $\mathrm{CH}_{2} \mathrm{Cl}_{2}(3 \times 50 \mathrm{ml})$. The organic layer was washed with sat. $\mathrm{NaCl}$ and dried over $\mathrm{Na}_{2} \mathrm{SO}_{4}$. After evaporation, the residue was distilled to give the product $3 \mathbf{a}$ in a yield of $1.23 \mathrm{~g}(50 \%)$, bp $150 \sim 155^{\circ} \mathrm{C} / 20 \mathrm{mmHg}$. The 1,2 -disubstituted piperidine $(3 \mathbf{a}, 480 \mathrm{mg}, 2.4 \mathrm{mmol})$ in $\mathrm{EtOH}(10 \mathrm{ml})$ was hydrogenated over $\mathrm{Pd}(\mathrm{OH})_{2} / \mathrm{C}^{12)}(200 \mathrm{mg})$ at ordinary pressure for $4 \mathrm{hr}$. After filtering the catalyst, $3 \mathrm{~N} \mathrm{HCl}$ $(0.8 \mathrm{ml})$ was added to the solution. The mixture was evaporated, and the residue was dissolved in water $(20 \mathrm{ml})$. After washing with ether $(3 \times 20 \mathrm{ml})$, the aqueous solution was made alkaline with $15 \% \mathrm{NaOH}$ and extracted with ether $(3 \times 30 \mathrm{ml})$. The organic layer was washed with sat. $\mathrm{NaCl}$ and dried over $\mathrm{Na}_{2} \mathrm{SO}_{4}$. After removing ether at ordinary pressure, the residue was distilled to give 2methylpiperidine (4a) in a yield of $100 \mathrm{mg}(43 \%)$, bp $90 \sim 95^{\circ} \mathrm{C} / 130 \mathrm{mmHg} .[\alpha]_{\mathrm{D}}^{25}+5.3^{\circ} \quad(c=1.6$, EtOH $) .{ }^{1} \mathrm{H}$ NMR $\delta: 0.8 \sim 2.0\left(\mathrm{~m}, 6 \mathrm{H},\left(\mathrm{CH}_{2}\right)_{3}\right), 1.07(\mathrm{~d}, J=6.4 \mathrm{~Hz}, 3 \mathrm{H}$, $\left.\mathrm{CH}_{3}\right), 1.6$ (broad s, $\left.1 \mathrm{H}, \mathrm{NH}\right), 2.3 \sim 3.3\left(\mathrm{~m}, 3 \mathrm{H}, \mathrm{CH}_{2} \mathrm{NCH}\right)$. Picrate: $\mathrm{mp} 133 \sim 134^{\circ} \mathrm{C}$ (lit. ${ }^{13)} 134 \sim 135^{\circ} \mathrm{C}$ for racemate, $116 \sim 117^{\circ} \mathrm{C}$ for $R$-form). Anal. Found: C, $43.82 ; \mathrm{H}, 4.81$; $\mathrm{N}, 17.08$. Calcd. for $\mathrm{C}_{12} \mathrm{H}_{16} \mathrm{~N}_{4} \mathrm{O}_{7}: \mathrm{C}, 43.91 ; \mathrm{H}, 4.91 ; \mathrm{N}$, 17.07 .

Asymmetric synthesis of (+)-coniine (4b). The disubstituted piperidine $\mathbf{3 b}$ was prepared according to the typical procedure. Hydrogenation of $\mathbf{3 b}$ afforded the product $\mathbf{4 b}$ in a yield of $30 \%$ from $1 \mathrm{~b}, \mathrm{bp} 110 \sim 120^{\circ} \mathrm{C} / 100 \mathrm{mmHg}$. $[\alpha]_{\mathrm{d}}^{23}+5.7^{\circ}$ (neat). ${ }^{1} \mathrm{H}$ NMR $\delta: 0.6 \sim 2.0 \quad(\mathrm{~m}, \quad 13 \mathrm{H}$, $\left.\mathrm{CH}_{2} \mathrm{CH}_{2} \mathrm{CH}_{3},\left(\mathrm{CH}_{2}\right)_{3}\right), 1.8$ (broad s, $\left.1 \mathrm{H}, \mathrm{NH}\right), 2.1 \sim 3.3$ (m, $3 \mathrm{H}, \mathrm{CH}_{2} \mathrm{NCH}$ ). 3,5-Dinitrobenzamide: $\mathrm{mp} 80 \sim 81^{\circ} \mathrm{C}$. Anal. Found: C, 55.89; H, 5.91; N, 13.13. Calcd. for $\mathrm{C}_{15} \mathrm{H}_{19} \mathrm{~N}_{3} \mathrm{O}_{5}$ : C, 56.07; H, 5.96; N, 13.08 .

Synthesis of optically pure (+)-coniine (4b). The disubstituted piperidine $\mathbf{3 b}$ already prepared was subjected to silica gel column chromatography (25\% EtOAc in hexane) to afford a diastereoisomer of $\mathbf{3 b}$ in an overall yield of $43 \%$ from 1b. $[\alpha]_{\mathrm{D}}^{25}+1.7^{\circ}(c=10.9$, EtOH $) .{ }^{1} \mathrm{H}$ NMR $\delta$ : $0.7 \sim 1.1\left(\mathrm{~m}, 3 \mathrm{H}, \mathrm{CH}_{2} \mathrm{CH}_{3}\right), 1.1 \sim 2.1\left(\mathrm{~m}, 10 \mathrm{H},\left(\mathrm{CH}_{2}\right)_{3}\right.$ and $\left.\left(\mathrm{CH}_{2}\right)_{2} \mathrm{CH}_{3}\right), 1.23\left(\mathrm{~d}, J=7.0 \mathrm{~Hz}, 3 \mathrm{H}, \mathrm{CHCH}_{3}\right), 2.1 \sim 3.0$ (m, 3H, $\left.\mathrm{CH}_{2} \mathrm{NCH}\right), 4.04$ (q, 1H, $\left.\mathrm{PhCH}\right), 7.1 \sim 7.6(\mathrm{~m}, 5 \mathrm{H}$, aromatic protons). Hydrogenation yielded optically pure $(+)$-coniine (4b) in a yield of $73 \% \cdot[\alpha]_{D}^{25}+14.8^{\circ}$ (neat).

Preparation of 1-cyclopentenecarboxylic acid and the methyl ester (5). A solution of $\mathrm{NaOH}(9.9 \mathrm{~g})$ in water (41 ml) was added to a solution of $\mathrm{AgNO}_{3}(21 \mathrm{~g})$ in water $(41 \mathrm{ml})$. The mixture was shaken, and 1-cyclopentenecarbaldehyde $^{14)}(6.0 \mathrm{~g}, 62 \mathrm{mmol})$ was added to it with ice-cooling. The mixture was shaken at room tempera- 
ture for $20 \mathrm{~min}$ and filtered. The aqueous filtrate was made acidic with conc. $\mathrm{HCl}$ to deposit the product acid in a yield of $6.1 \mathrm{~g}(87 \%)$. The acid $(5.0 \mathrm{~g}, 45 \mathrm{mmol})$ was heated in $\mathrm{MeOH}(50 \mathrm{ml})$ with conc. $\mathrm{H}_{2} \mathrm{SO}_{4}(1 \mathrm{ml})$ under reflux for $4 \mathrm{hr}$. After evaporation, the residue was dissolved in ether $(100 \mathrm{ml})$. The solution was washed with sat. $\mathrm{NaHCO}_{3}$ and sat. $\mathrm{NaCl}$. Distillation gave the ester 5 in a yield of $4.2 \mathrm{~g}\left(75^{\circ}\right)$, bp $85 \sim 87^{\circ} \mathrm{C} / 25 \mathrm{mmHg} \cdot{ }^{1} \mathrm{H}$ NMR $\delta: 1.7 \sim 2.8\left(\mathrm{~m}, 6 \mathrm{H},\left(\mathrm{CH}_{2}\right)_{3}\right), 3.69\left(\mathrm{~s}, 3 \mathrm{H}, \mathrm{OCH}_{3}\right)$, $6.5 \sim 6.8(\mathrm{~m}, 1 \mathrm{H},=\mathrm{CH}-)$.

Asymmetric synthesis of (+)-pipecolic acid (7). Ozone gas was passed into a mixture of $5(2.0 \mathrm{~g}, 15.9 \mathrm{mmol})$, $\mathrm{MeOH}(10 \mathrm{ml})$ and $\mathrm{CH}_{2} \mathrm{Cl}_{2}(20 \mathrm{ml})$ at $60^{\circ} \mathrm{C}$, until a blue color developed. After removing the excess ozone with $\mathrm{N}_{2}, \mathrm{NaBH}_{3} \mathrm{CN}(1.0 \mathrm{~g}, 15.9 \mathrm{mmol})$ and $\mathrm{MeOH}$ $(10 \mathrm{ml})$ were added to the solution, and the mixture was stirred at $-60^{\circ} \mathrm{C}$ for $30 \mathrm{~min}$. A mixture of the amine $2 \mathrm{a}(1.9 \mathrm{~g}, 15.7 \mathrm{mmol})$, acetic acid $(0.9 \mathrm{~g}, 15.0$ mmol) and $\mathrm{MeOH}(30 \mathrm{ml})$ was added to the solution at $-60^{\circ} \mathrm{C}$. Stirring was continued at $0^{\circ} \mathrm{C}$ for $15 \mathrm{hr}$. After removing the solvent under reduced pressure, sat. $\mathrm{NaHCO}_{3}(30 \mathrm{ml})$ was added. The mixture was extracted with $\mathrm{CH}_{2} \mathrm{Cl}_{2}(3 \times 50 \mathrm{ml})$. The organic layer was washed with sat. $\mathrm{NaCl}$ and dried over $\mathrm{Na}_{2} \mathrm{SO}_{4}$. After evaporation, the residue was subjected to silica gel drycolumn chromatography $(40 \%$ EtOAc in hexane) to afford a diastereoisomeric mixture of the product 6 in a yield of $0.93 \mathrm{~g}(24 \%)$. The amino ester $6(0.9 \mathrm{~g}$, $3.6 \mathrm{mmol})$ in $\mathrm{MeOH}(50 \mathrm{ml})$ was hydrogenated over $\mathrm{Pd}(\mathrm{OH})_{2} / \mathrm{C}(250 \mathrm{mg})$ at ordinary pressure for $2 \mathrm{hr}$. After filtering off the catalyst, evaporation gave an oil $(0.53 \mathrm{~g})$. This oil was dissolved in $\mathrm{MeOH}(2 \mathrm{ml})$ and treated with $6 \mathrm{~N} \mathrm{NaOH}(0.7 \mathrm{ml})$ at room temperature for $2 \mathrm{hr}$. Ion exchange resin of IR-120B (pyridine type) was added to neutralize the solution. After filtration, the solution was washed with $\mathrm{CH}_{2} \mathrm{Cl}_{2}(20 \mathrm{ml})$, and then evaporated. The residue was purified by sublimation at $200^{\circ} \mathrm{C} / 0.1 \mathrm{mmHg}$ to afford 7 in a yield of $0.4 \mathrm{~g}\left(85^{\circ}\right) \cdot[\alpha]_{\mathrm{D}}^{21}+20.4^{\circ}(c=1.0$, water). ${ }^{1} \mathrm{H} \quad \mathrm{NMR} \quad\left(\mathrm{D}_{2} \mathrm{O}\right) \quad \delta: 1.3 \sim 2.6 \quad(\mathrm{~m}, \quad 6 \mathrm{H}$, $\left.\left(\mathrm{CH}_{2}\right)_{3}\right), 2.6 \sim 4.0\left(\mathrm{~m}, 3 \mathrm{H}, \mathrm{CH}_{2} \mathrm{NCH}\right)$. Anal. Found: C, 55.42; $\mathrm{H}, 8.44 ; \mathrm{N}, 10.70$. Calcd. for $\mathrm{C}_{6} \mathrm{H}_{11} \mathrm{NO}_{2}$ : C, 55.80; $\mathrm{H}, 8.58 ; \mathrm{N}, 10.84$

Synthesis of optically pure (+)-pipecolic acid (7). The amino ester 6 just prepared was subjected to silica gel preparative thin-layer chromatography (ptlc, 10\% EtOAc in hexane) to afford a diastereoisomer of 6 in an overall yield of $22 \%$ from $5 .[\alpha]_{\mathrm{D}}^{25}-15.9^{\circ}(c=1.38$, EtOH $) .{ }^{1} \mathrm{H}$ NMR $\delta: 1.1 \sim 2.2\left(\mathrm{~m}, 6 \mathrm{H},\left(\mathrm{CH}_{2}\right)_{3}\right), 1.30(\mathrm{~d}, J=7.0 \mathrm{~Hz}, 3 \mathrm{H}$, $\left.\mathrm{CHCH}_{3}\right), 2.2 \sim 3.0\left(\mathrm{~m}, 2 \mathrm{H}, \mathrm{CH}_{2} \mathrm{~N}\right), 3.75\left(\mathrm{~s}, 3 \mathrm{H}, \mathrm{OCH}_{3}\right)$, $3.7 \sim 4.0(\mathrm{~m}, 1 \mathrm{H}, \mathrm{NCH}), 3.95(\mathrm{q}, 1 \mathrm{H}, \mathrm{PhCH}), 7.1 \sim 7.6(\mathrm{~m}$, $5 \mathrm{H}$, aromatic protons). Successive hydrogenation and hydrolysis yielded optically pure $(+)-7$ in a yield of $74 \% \cdot[\alpha]_{\mathrm{D}}^{25}+24.0^{\circ}(c=1.04$, water $)$.

Assessment of the e.e. of pipecolic acid (7) by HPLC.
Pipecolic acid (7, $42 \mathrm{mg}, 0.33 \mathrm{mmol})$ was dissolved in $1 \mathrm{~N}$ $\mathrm{NaOH}(0.73 \mathrm{ml})$. Benzyl chloroformate $(61 \mathrm{mg}, 0.36$ mmol) was added, and the mixture was shaken with icecooling for $10 \mathrm{~min}$ and then at room temperature for $1 \mathrm{hr}$. The mixture was diluted with water $(2 \mathrm{ml})$ and washed with ether $(3 \times 1 \mathrm{ml})$. The aqueous solution was made acidic with $6 \mathrm{~N} \mathrm{HCl}$ and extracted with EtOAc $(3 \times 2 \mathrm{ml})$. The organic layer was washed with sat. $\mathrm{NaCl}$ and dried over $\mathrm{Na}_{2} \mathrm{SO}_{4}$. Evaporation gave carbobenzyloxypipecolic acid in a yield of $83 \mathrm{mg}(97 \%)$. This compound ( $26 \mathrm{mg}, 0.1$ $\mathrm{mmol})$ and $(S)$-valine methyl ester hydrochloride $(17 \mathrm{mg}$, $0.1 \mathrm{mmol})$ were dissolved in $\mathrm{CH}_{2} \mathrm{Cl}_{2}(0.5 \mathrm{ml})$. DCC (21 mg, $0.1 \mathrm{mmol})$ and $\mathrm{Et}_{3} \mathrm{~N}(10 \mathrm{mg}, 0.1 \mathrm{mmol})$ were added to the solution at $0^{\circ} \mathrm{C}$. Stirring was continued at $0^{\circ} \mathrm{C}$ for $2 \mathrm{hr}$ and then at room temperature for $2 \mathrm{hr}$. After filtering, evaporation gave the dipeptide 8 in a yield of $25 \mathrm{mg}$ $(66 \%)$. HPLC analysis was performed on the sample under the conditions already described.

Preparation of 1-cyclopentenemethanol (9a). 1Cyclopentenecarbaldehyde (3.0 g, $31 \mathrm{mmol})$ was dissolved in $\mathrm{MeOH}(30 \mathrm{ml})$ and treated with $\mathrm{NaBH}_{4}(0.8 \mathrm{~g}, 21 \mathrm{mmol})$ at $0^{\circ} \mathrm{C}$ for $1 \mathrm{hr}$. After adding water $(50 \mathrm{ml})$, the mixture was extracted with $\mathrm{CH}_{2} \mathrm{Cl}_{2}(4 \times 30 \mathrm{ml})$. The organic layer was washed with sat. $\mathrm{NaCl}$ and dried over $\mathrm{Na}_{2} \mathrm{SO}_{4}$. Distillation gave the alcohol 9a in a yield of $2.6 \mathrm{~g} \mathrm{(85 \% ),} \mathrm{bp}$ $88 \sim 89^{\circ} \mathrm{C} / 18 \mathrm{mmHg}$ (lit ${ }^{15)}$ bp $66 / 11 \mathrm{mmHg}$ ). ${ }^{1} \mathrm{H} \mathrm{NMR}$ $\delta: 1.5 \sim 2.5\left(\mathrm{~m}, 6 \mathrm{H},\left(\mathrm{CH}_{2}\right)_{3}\right), 3.6($ broad $\mathrm{s}, 1 \mathrm{H}, \mathrm{OH})$, 4.1 (broad s, $\left.2 \mathrm{H}, \mathrm{OCH}_{2}\right), 5.4 \sim 5.6(\mathrm{~m}, 1 \mathrm{H},=\mathrm{CH}-)$.

Preparation of the trimethylacetate $(9 \mathbf{b})$. The alcohol 9a $(2.9 \mathrm{~g}, 30 \mathrm{mmol})$ was dissolved in pyridine $(27 \mathrm{ml})$ and treated with trimethylacetyl chloride $(4.0 \mathrm{~g}, 33 \mathrm{mmol})$ at $0^{\circ} \mathrm{C}$ for $2 \mathrm{hr}$. After adding a few drops of water, the solvent was distilled off under reduced pressure, and the residue was dissolved in $\mathrm{CH}_{2} \mathrm{Cl}_{2}(100 \mathrm{ml})$. The solution was washed successively with $6 \mathrm{~N} \mathrm{HCl}$, sat. $\mathrm{NaHCO}_{3}$ and sat. $\mathrm{NaCl}$, and then dried over $\mathrm{Na}_{2} \mathrm{SO}_{4}$. Distillation gave the ester 9b in a yield of $5.1 \mathrm{~g}(93 \%)$, bp $105 \sim 110^{\circ} \mathrm{C} / 15 \mathrm{mmHg} .{ }^{1} \mathrm{H}$ NMR $\delta: 1.22\left(\mathrm{~s}, 9 \mathrm{H},\left(\mathrm{CH}_{3}\right)_{3}\right)$, $1.7 \sim 2.5\left(\mathrm{~m}, 6 \mathrm{H},\left(\mathrm{CH}_{2}\right)_{3}\right), 4.5 \sim 4.7\left(\mathrm{~m}, 2 \mathrm{H}, \mathrm{OCH}_{2}\right)$, $5.5 \sim 5.7(\mathrm{~m}, 1 \mathrm{H},=\mathrm{CH}-)$.

Preparation of the trimethylsilyl ether $(\mathbf{9 c})$. The alcohol $9 \mathrm{a}(1.5 \mathrm{~g}, 15 \mathrm{mmol})$ was dissolved in a mixture of pyridine $(1.3 \mathrm{ml})$ and $\mathrm{CH}_{2} \mathrm{Cl}_{2}(13 \mathrm{ml})$. Chlorotrimethylsilane $(1.8 \mathrm{~g}$, $17 \mathrm{mmol}$ ) was added to the solution at $0^{\circ} \mathrm{C}$ and stirring was continued at $0^{\circ} \mathrm{C}$ for $1 \mathrm{hr}$. After filtering, distillation gave the product $9 \mathrm{c}$ in a yield of $2.1 \mathrm{~g}(83 \%)$, bp $90 \sim 95 / 20$ mmHg. ${ }^{1} \mathrm{H}$ NMR $\delta: 0.21\left(\mathrm{~s}, 9 \mathrm{H}, \mathrm{Si}\left(\mathrm{CH}_{3}\right)_{3}\right), 1.6 \sim 2.6(\mathrm{~m}$, $\left.6 \mathrm{H},\left(\mathrm{CH}_{2}\right)_{3}\right), 4.1 \sim 4.3\left(\mathrm{~m}, 2 \mathrm{H}, \mathrm{OCH}_{2}\right), 5.5 \sim 5.7(\mathrm{~m}, 1 \mathrm{H}$, $=\mathrm{CH}-$ ).

Asymmetric synthesis of (-)-2-hydroxymethylpiperidine (11) from the ester (9b); typical procedure. Ozonolysis and aminocyclization were performed as described for the asymmetric synthesis of 7 . In the case using the esters $9 a$ 
and $9 c$, the following operation of hydrolysis was not necessary. The 1,2-disubstituted piperidine thus obtained (crude $2.7 \mathrm{~g}$ ) from $9 \mathrm{~b}(1.7 \mathrm{~g}, 9.3 \mathrm{mmol})$ was hydrolyzed with $5 \% \mathrm{KOH}$ in $\mathrm{MeOH}(50 \mathrm{ml})$ at room temperature overnight. After evaporation, water $(50 \mathrm{ml})$ was added to the residue. The mixture was extracted with $\mathrm{CH}_{2} \mathrm{Cl}_{2}$ $(2 \times 50 \mathrm{ml})$, and the organic layer was washed with sat. $\mathrm{NaCl}$ and dried over $\mathrm{Na}_{2} \mathrm{SO}_{4}$. Evaporation gave the amino alcohol 10 in a yield of $1.6 \mathrm{~g}$ (crude). Hydrogenation was carried out as described for 7 to afford the crude product as an oil $(1.1 \mathrm{~g})$. The oil dissolved in water $(10 \mathrm{ml})$ was passed through a Sep-Pack $\mathrm{C}_{18}$ cartridge, and the cartridge was washed with water $(10 \mathrm{ml})$. The combined aqueous solution was passed through IRA-400 ion-exchange resin $\left(\mathrm{OH}^{-}\right.$form, $\left.20 \mathrm{ml}\right)$, and the column was washed with water $(30 \mathrm{ml})$. The combined eluent was concentrated under reduced pressure. Distillation gave the product 11 in a yield of $0.56 \mathrm{~g}(58 \%)$, bp $100 \sim 102^{\circ} \mathrm{C} / 2 \mathrm{mmHg}$ (lit. ${ }^{16)}$ $\left.98 \sim 102^{\circ} \mathrm{C} / 1 \mathrm{mmHg}\right) .[\alpha]_{\mathrm{D}}^{20}-13.5^{\circ}(c=2.38$, EtOH $) .{ }^{1} \mathrm{H}$ NMR $\delta: 0.9 \sim 2.1\left(\mathrm{~m}, 6 \mathrm{H},\left(\mathrm{CH}_{2}\right)_{3}\right), 2.3 \sim 3.2(\mathrm{~m}, 3 \mathrm{H}$, $\left.\mathrm{CH}_{2} \mathrm{NCH}\right), 3.2 \sim 3.7\left(\mathrm{~m}, 2 \mathrm{H}, \mathrm{OCH}_{2}\right), 3.9$ (broad s, $2 \mathrm{H}$, $\mathrm{NH}$ and $\mathrm{OH}$ ). Picrate: $\mathrm{mp} 132 \sim 133^{\circ} \mathrm{C}$ (lit. ${ }^{16)} \mathrm{mp}$ $135 \sim 137^{\circ} \mathrm{C}$ for racemate, $102 \sim 105^{\circ} \mathrm{C}$ for $R$-form). Anal. Found: C, 41.24; H, 4.57; N, 16.15. Calcd. for $\mathrm{C}_{12} \mathrm{H}_{16} \mathrm{~N}_{4} \mathrm{O}_{8}: \mathrm{C}, 41.87 ; \mathrm{H}, 4.68 ; \mathrm{N}, 16.27$.

\section{REFERENCES AND NOTES}

1) C. F. Lane, Synthesis, 1975, 135.

2) K. Abe, H. Okumura, T. Tsugoshi and N. Nakamura, Synthesis, 1984, 597; K. Abe, T. Tsugoshi and N. Nakamura, Bull. Chem. Soc. Jpn., 57, 3351 (1984).

3) M. Kawaguchi, J. Ohashi, Y. Kawakami, Y. Yamamoto and J. Oda, Synthesis, 1985, 701.

4) M. B. Watson and G. W. Youngson, J. Chem. Soc.,
1954, 2145.

5) A. F. Plate and A. A. Mel'nikov, Zhur. Obshchei Khim., 29, 1064 (1959) [C. A., 54, 1347c (1960)].

6) J. C. Craig and A. R. Pinder, J. Org. Chem., 36, 3648 (1971).

7) Starting from the $t$-butyl ester in place of the methyl ester $\mathbf{5}$, the amino ester $\mathbf{6}$ with a $t$-butyl group was obtained in a yield of $31 \%$, whose diastereoisomeric ratio was determined to be $83: 17$ by chromatographic separation.

8) R. J. Hemingway, J. Pharm. Pharmac., 20, 87 (1968).

9) T. Fujii and M. Miyoshi, Bull. Chem. Soc. Jpn., 48, 1341 (1975).

10) The cyclic olefin having the $(S)$-valine methyl ester moiety in place of the $\mathrm{OCH}_{3}$ group in $\mathbf{5}$ was subjected to the present asymmetric synthesis using benzylamine and 2a. The dipeptide $\mathbf{8}$ was formed as the final product through hydrogenation and carbobenzyloxylation, and the diastereoisomeric ratios of $\mathbf{8}$ were determined by HPLC to be $52: 48$ and $82: 18$ when benzylamine and 2a were employed, respectively. The chirality of the valine moiety was found to make only a small influence on the asymmetric synthesis.

11) Org. Syn., Coll. Vol. 5, p. 932.

12) R. G. Hiskey and R. C. Northrop, J. Am. Chem. Soc., 83, 4798 (1961).

13) A. Lipp, Justus Liebigs Ann. Chem., 289, 173 (1896); W. Marckwald, Chem. Ber., 29, 43 (1896).

14) J. B. Brown, H. B. Henbest and E. R. H. Jones, J. Chem. Soc., 1950, 3634.

15) E. Urion, Compt. Rend., 198, 1518 (1934).

16) F. F. Blicke and C-J. Lu, J. Am. Chem. Soc., 77, 29 (1955); H. Ripperger and K. Schreiber, Tetrahedron, 21, 1485 (1965). 